\title{
ANTITERMITIC AND ANTIFUNGAL ACTIVITIES OF ESSENTIAL OIL OF Calocedrus formosana LEAF AND ITS COMPOSITION
}

\author{
SEN-SUNG CHENG, CHI-LIN WU, HUI-TING CHANG, \\ YU-TING KAO, and SHANG-TZEN CHANG* \\ School of Forestry and Resource Conservation \\ National Taiwan University, No. 1, Section 4 \\ Roosevelt Road, Taipei 106, Taiwan
}

(Received November 4, 2003; accepted June 16, 2004)

\begin{abstract}
Calocedrus formosana Florin (Cupressaceae) is an endemic tree species in Taiwan; its timber is recognized for natural decay resistance. To examine the antitermitic and antifungal activities of leaf essential oil and its main constituents, $C$. formosana leaves were extracted and the essential oils analyzed by GC-MS. Bioactivity tests against the termite Coptotermes formosanus demonstrate that the $\mathrm{LC}_{50}$ value of leaf essential oil is $27.6 \mathrm{mg} / \mathrm{g}$. Furthermore, exposure to T-muurolol caused $100 \%$ mortality at a dosage of $5 \mathrm{mg} / \mathrm{g}$ after $14 \mathrm{~d}$. Leaf oil constituents displayed activity against four fungi, Lenzites betulina, Pycnoporus coccineus, Trametes versicolor, and Laetiporus sulphureus. Two compounds, $\alpha$-cadinol and T-muurolol, exhibited the strongest antifungal activity. The $\mathrm{LC}_{50}$ values of $\alpha$-cadinol against $L$. sulphureus, L. betulina, and $T$. versicolor are 9.9, 28.6, and $30.4 \mu \mathrm{g} / \mathrm{ml}$, respectively.
\end{abstract}

Key Words-Calocedrus formosana, leaf, essential oil, GC-MS, Coptotermes formosanus, antitermitic activity, antifungal activity, $\alpha$-cadinol, T-muurolol.

\section{INTRODUCTION}

Wood, a naturally occurring polymer composite, is mainly composed of cellulose, hemicelluloses, lignin, and extractives. Due to its biological nature, unprotected wood is susceptible to discoloration and biological deterioration, which reduce its mechanical and physical properties (Chang et al., 2002). Developing methods that prolong the service life of wood has always been the interest of wood researchers. From an environmental perspective, finding naturally occurring constituents in

\footnotetext{
* To whom correspondence should be addressed. E-mail: peter@ntu.edu.tw
} 
highly durable tree species and understanding their mechanisms are the most appropriate approaches to achieving wood protection while preserving the environment (Chang et al., 2000). In recent years, many studies have investigated the relationship between wood properties and wood essential oils (Kinjo and Yata, 1986; Kondo and Imamura, 1986; Asada et al., 1989; Yoneyama et al., 1990; Nabeta et al., 1992; Morita et al., 1997; Chang et al., 2001a,b; Chang and Cheng, 2002). Therefore, extraction of natural compounds having specific bioactivies and/or medicinal properties from plants is an important application of natural product research.

Due to the unique ecosystem, there are many valuable tree species endemic to Taiwan. In the past few years, we have studied the relationship between wood properties and chemical constituents of endemic trees in Taiwan. In previous studies, we found that Taiwania cryptomerioides, Cinnamomum osmophloeum, and Cryptomeria japonica possess significant antifungal and antitermitic activity (Chang et al., 1998, 1999, 2001a,b; Chang and Cheng, 2002; Cheng and Chang, 2002).

Calocedrus formosana Florin (Cupressaceae) is an indigenous tree that grows at elevations of 800-1500 $\mathrm{m}$ in the northern part of the central mountain region of Taiwan and is one of the five useful conifer trees in Taiwan. Calocedrus is named for its beauty and resin. The wood is pale yellow in color. The physical-chemical properties of the timbers of this plant are recognized for their decay resistance, durability, and an incense-like smell. Its essential oil, of which the acidic constituents (shonanic acid) in particular, was investigated in 1932 by Ichikawa (Lo and Lin, 1956). More than 50 compounds have been isolated including monoterpenes, diterpenes, lignans, and steroids (Lin et al., 1956; Cheng et al., 1961; Fang et al., 1985, 1987, 1989a,b). C. formosana leaves have been found to be a suitable cell culture material for hinokitiol (a strong antimicrobial compound) and have the highest hinokitiol production among tested members of the Cupressaceae family (Mikage et al., 1988; Ono et al., 1998). However, there has been little research into the relationship between its wood properties and various extractives. For this reason, the essential oil of $C$. formosana leaves was distilled and its constituents analyzed by GC-MS. The antitermitic activities of the essential oil and isolated constituents against the termite Coptotermes formosanus were investigated using direct contact application. In addition, the antifungal activities of these constituents against four wood-rot fungi-Laetiporus sulphureus, Pycnoporus coccineus, Lenzites betulina, and Trametes versicolor-were also examined.

\section{METHODS AND MATERIALS}

Termite. Coptotermes formosanus Shiraki, was collected from Tainan in southern Taiwan. The colony was reared in an incubator at $26.5^{\circ} \mathrm{C}$ and $80 \%$ $\mathrm{RH}$ for more than 1 year. Water and newspapers were used as food sources. 
Fungi. Three white-rot fungi [Lenzites betulina (CCRC 35296), Pycnoporus coccineus, and Trametes versicolor (CCRC 35253)] and one brown-rot fungus [Laetiporus sulphureus (CCRC 35305)], were used in these experiments. L. betulina, T. versicolor, and L. sulphureus were obtained from the culture collection and research center of the Food Industry Research and Development Institute in Taiwan. $P$. coccineus was a gift provided by Dr. Tun-Tschu Chang (Taiwan Forestry Research Institute).

Essential Oil Distillation. Leaves of 41-year-old C. formosana were collected from the Experimental Forest of the National Taiwan University in central Taiwan. Leaf essential oils were extracted by water distillation ( $8 \mathrm{hr}$ ).

Gas Chromatography-Mass Spectrometry (GC-MS) Analysis. The chemical composition of the essential oil was analyzed using GC-MS. An Agilent Technologies HP 5973N mass selective detector in the electron impact (EI) ionization mode $(70 \mathrm{eV})$ was used in conjunction with a Hewlett-Packard 6890 gas chromatograph. Leaf oil constituents were separated under the following conditions: capillary column, HP-1MS $(30 \mathrm{~m} \times 0.25 \mathrm{~mm}$; film thickness $0.25 \mu \mathrm{m})$; temperature program, $50^{\circ} \mathrm{C}$ (held for $5 \mathrm{~min}$ ) raised to $120^{\circ} \mathrm{C}$ at a rate of $2^{\circ} \mathrm{C} / \mathrm{min}$ and from $120^{\circ} \mathrm{C}$ to $220^{\circ} \mathrm{C}$ at a rate of $5^{\circ} \mathrm{C} / \mathrm{min}$ held for $5 \mathrm{~min}$; injector temperature, $270^{\circ} \mathrm{C}$; and carrier gas, helium, at a flow rate of $1 \mathrm{ml} / \mathrm{min}$. Split ratio was 1:10. Identification of the components of $C$. formosana leaf oil was confirmed by comparison with standards as well as by spiking. The quantity of compounds was obtained by integrating the peak area of the spectrograms.

Essential Oil Constituents. The following essential oil constituents were purchased from Acros (Belgium): $\alpha$-pinene, $\beta$-pinene, $\beta$-myrcene, limonene, $\beta$-caryophyllene, and caryophyllene oxide. $\alpha$-Cadinol and T-muurolol were isolated from leaf essential oil.

Antitermitic Activity. The no-choice bioassay method of Kang et al. (1990) was used to evaluate antitermitic activity. Samples of 10,25 , and $50 \mathrm{mg}$ of leaf essential oil as well as 1 and $5 \mathrm{mg}$ of each individual compound dissolved in $600 \mu \mathrm{l}$ of acetone were applied to $1 \mathrm{~g}$ filter paper samples (Whatman \#3, $8.5 \mathrm{~cm}$ in diam). A piece of filter paper treated with solvent only was used as control. After air-drying at room temperature, 50 active termites (45 workers and 5 soldiers) above the third instar were placed onto each filter paper impregnated with the test materials in a Petri dish $(9 \mathrm{~cm}$ diam $\times 1.5 \mathrm{~cm}$ height $)$. The test dishes with covers were then placed into an incubator maintained at $26.5^{\circ} \mathrm{C}$ and $80 \% \mathrm{RH}$. A few drops of water were periodically added to the bottom edge of each Petri dish. Three replicates were prepared for each test sample, and the mortality of the termites was counted daily for $14 \mathrm{~d}$.

Antifungal Assay. The method of Chang et al. (1999) was employed for antifungal evaluation of both the essential oil and its main constituents, which were tested at 1000, 200,100, and $50 \mu \mathrm{g} / \mathrm{ml}$ concentrations against L. betulina, $P$. coccineus, $T$. versicolor, and L. sulphureus in $9 \mathrm{~cm}$ Petri dishes. Antifungal assays were performed three times. After fungal mycelia reached the edges of 
control plates (without adding essential oils or compounds) by incubating at $26^{\circ} \mathrm{C}$ for ca. $10 \mathrm{~d}$, the antifungal index was calculated as follows: Antifungal index $(\%)=$ $(1-\mathrm{Da} / \mathrm{Db}) \times 100$ where, $\mathrm{Da}=$ the diameter of growth zone in the experimental plate $(\mathrm{cm}), \mathrm{Db}=$ the diameter of growth zone in the control plate $(\mathrm{cm})$.

Statistical Analyses. All results were obtained from three independent experiments and expressed as mean \pm SD. Significant differences $(P<0.05)$ were determined by using the Scheffe test.

\section{RESULTS AND DISCUSSION}

Yields and Chemical Constituents of Essential Oil. The leaf essential oil of $C$. formosana was obtained in a yield of $0.3 \%$ (or $3.4 \mathrm{ml} / \mathrm{kg}$ ) dry weight. GC-MS analysis of the essential oil is shown in Table 1, where components are listed in order of their elution from the HP-1MS column. Nineteen constituents, accounting for more than $94.0 \%$ of the total oil composition, were identified. Nine monoterpenes $(78.0 \%)$ and ten sesquiterpenes $(16.5 \%)$ were identified in the essential oil. The main components of the leaf essential oil were $\alpha$-pinene (44.2\%),

TABle 1. Constituents of EsSENTIAL OIL FROM Calocedrus formosana LEAVES

\begin{tabular}{lrrr}
\hline \multicolumn{1}{c}{ Compounds } & $R_{\mathrm{t}}(\mathrm{min})^{a}$ & Formula & $\% \mathrm{RA}^{b}$ \\
\hline Tricyclene & 6.39 & $\mathrm{C}_{10} \mathrm{H}_{16}$ & 0.25 \\
$\alpha$-Pinene & 7.29 & $\mathrm{C}_{10} \mathrm{H}_{16}$ & 44.23 \\
Camphene & 7.86 & $\mathrm{C}_{10} \mathrm{H}_{16}$ & 0.42 \\
$\beta$-Phellandrene & 9.52 & $\mathrm{C}_{10} \mathrm{H}_{16}$ & 0.39 \\
$\beta$-Pinene & 9.64 & $\mathrm{C}_{10} \mathrm{H}_{16}$ & 1.20 \\
$\beta$-Myrcene & 11.09 & $\mathrm{C}_{10} \mathrm{H}_{16}$ & 8.92 \\
Limonene & 13.58 & $\mathrm{C}_{10} \mathrm{H}_{16}$ & 21.57 \\
4-Carene & 17.71 & $\mathrm{C}_{10} \mathrm{H}_{16}$ & 0.55 \\
4-Terpineol & 23.47 & $\mathrm{C}_{10} \mathrm{H}_{18} \mathrm{O}$ & 0.48 \\
$\beta$-Caryophyllene & 40.09 & $\mathrm{C}_{15} \mathrm{H}_{24}$ & 8.23 \\
$\alpha$-Caryophyllene & 41.83 & $\mathrm{C}_{15} \mathrm{H}_{24}$ & 0.82 \\
$\alpha$-Cadinene & 44.06 & $\mathrm{C}_{15} \mathrm{H}_{24}$ & 0.30 \\
$\gamma$-Cadinene & 44.48 & $\mathrm{C}_{15} \mathrm{H}_{24}$ & 0.24 \\
$\delta$-Cadinene & 44.91 & $\mathrm{C}_{15} \mathrm{H}_{24}$ & 0.87 \\
Elemol & 45.61 & $\mathrm{C}_{15} \mathrm{H}_{26} \mathrm{O}$ & 0.68 \\
Caryophyllene oxide & 46.56 & $\mathrm{C}_{15} \mathrm{H}_{24} \mathrm{O}$ & 2.44 \\
$\gamma$-Eudesmol & 48.22 & $\mathrm{C}_{15} \mathrm{H}_{26} \mathrm{O}$ & 0.25 \\
T-Muurolol & 48.48 & $\mathrm{C}_{15} \mathrm{H}_{26} \mathrm{O}$ & 1.09 \\
$\alpha$-Cadinol & 48.81 & $\mathrm{C}_{15} \mathrm{H}_{26} \mathrm{O}$ & 1.56 \\
\hline
\end{tabular}

${ }^{a} R_{\mathrm{t}}$ : Retention time.

${ }^{b} \mathrm{RA}$ : Relative area (peak area relative to total peak area). 
<smiles>CC1=CCC2CC1C21CC1</smiles><smiles>C=C1CC2C3CC1C2C3</smiles>

$\alpha$-pinene

$\beta$-pinene<smiles>C=CC(=C)CCC=C(C)C</smiles>

$\beta$-myrcene<smiles>C=C(C)C1CC=C(C)CC1</smiles>

limonene

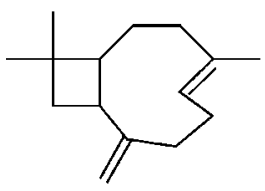

$\beta$-caryophyllene

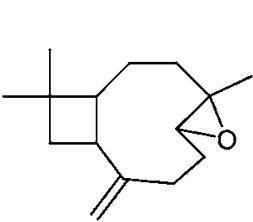

caryophyllene oxide<smiles>CC1=C[C@H]2[C@@H](C(C)C)CC[C@H](C)[C@H]2CC1</smiles>

T-muurolol<smiles>CC1=C[C@H]2[C@@H](C(C)C)CC[C@H](C)[C@H]2CC1</smiles>

$\alpha$-cadinol

FIG. 1. Structures of terpenoids from Calocedrus formosana leaf essential oil.

limonene $(21.6 \%), \beta$-myrcene $(8.9 \%), \beta$-caryophyllene $(8.2 \%)$, caryophyllene oxide $(2.4 \%), \alpha$-cadinol (1.6\%), $\beta$-pinene (1.2\%), and T-muurolol $(1.1 \%)$. The chemical structures of these compounds are shown in Figure 1.

Antitermitic Activity. The antitermitic activity of $C$. formosana essential oil and various isolated constituents are shown in Figure 2. At a dosage of $10 \mathrm{mg} / \mathrm{g}$, the leaf essential oil killed $26.7 \%$ of the termites after $14 \mathrm{~d}$. Termite mortality increased to $76.7 \%$ when dosage was increased to $50 \mathrm{mg} / \mathrm{g}$. The $\mathrm{LC}_{50}$ value of leaf essential oil against $C$. formosanus was $27.6 \mathrm{mg} / \mathrm{g}$.

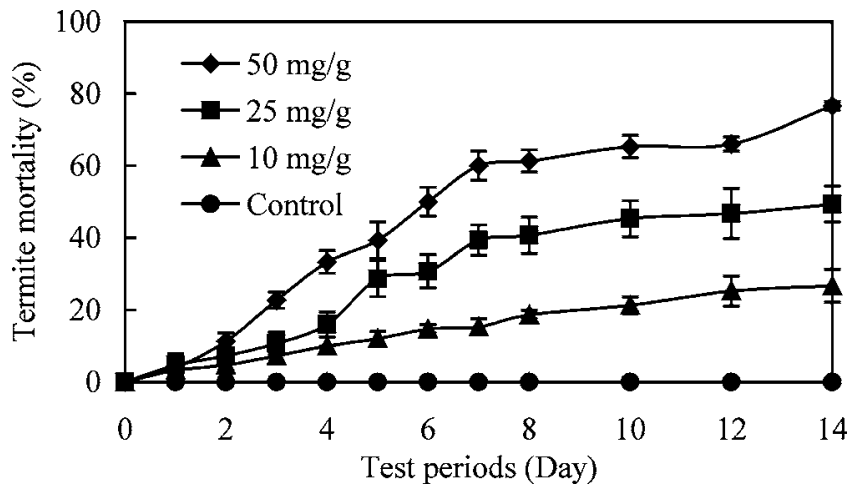

FIG. 2. Antitermitic activity of leaf essential oil from Calocedrus formosana against Coptotermes formosanus. Means $(N=3)$ using 50 termites per replicate. 
TABLE 2. ANTITERMitic ACTIVITY OF EIGHT EsSENTIAL OIL CONSTITUENTS FROM Calocedrus formosana LEAVES AT $1 \mathrm{mg} / \mathrm{g}$ DOSAGE

\begin{tabular}{lcc}
\hline \multirow{2}{*}{ Compounds } & \multicolumn{2}{c}{ Termite mortality $^{a}(\%)$} \\
\cline { 2 - 3 } & \multicolumn{1}{c}{$7 \mathrm{~d}$} & $14 \mathrm{~d}$ \\
\hline Limonene & $1.3 \pm 2.3 \mathrm{c}$ & $1.3 \pm 2.3 \mathrm{e}$ \\
$\beta$-Caryophyllene & $19.3 \pm 2.3 \mathrm{a}$ & $25.3 \pm 2.3 \mathrm{a}$ \\
$\alpha$-Pinene & $2.7 \pm 1.2 \mathrm{c}$ & $5.3 \pm 2.3 \mathrm{c}, \mathrm{d}, \mathrm{e}$ \\
$\beta$-Pinene & $4.0 \pm 2.0 \mathrm{c}$ & $7.3 \pm 3.1 \mathrm{c}, \mathrm{d}, \mathrm{e}$ \\
$\beta$-Myrcene & $7.3 \pm 3.1 \mathrm{~b}, \mathrm{c}$ & $11.3 \pm 4.6 \mathrm{~b}, \mathrm{c}, \mathrm{d}$ \\
Caryophyllene oxide & $13.3 \pm 4.6 \mathrm{a}, \mathrm{b}$ & $17.3 \pm 1.2 \mathrm{a}, \mathrm{b}$ \\
T-Muurolol & $2.0 \pm 0.0 \mathrm{c}$ & $2.0 \pm 0.0 \mathrm{~d}, \mathrm{e}$ \\
$\alpha$-Cadinol & $5.3 \pm 3.1 \mathrm{~b}, \mathrm{c}$ & $14.0 \pm 4.0 \mathrm{~b}, \mathrm{c}$ \\
Control & $0.0 \pm 0.0 \mathrm{e}$ & $0.0 \pm 0.0 \mathrm{e}$ \\
\hline
\end{tabular}

${ }^{a}$ Means $(N=3)$ using 50 termites per replicate. Numbers followed by different letters $(\mathrm{a}-\mathrm{e})$ are significantly different at the level of $P<0.05$ according to the Scheffe test.

Antitermitic Activity of Isolated Constituents. To understand the relationship between the main constituents of $C$. formosana essential oil and antitermitic activity, eight constituents were tested for antitermitic activity. Table 2 shows the activity of these constituents at a dose of $1 \mathrm{mg} / \mathrm{g} . \beta$-Caryophyllene (19.3\%) and caryophyllene oxide (13.3\%) caused the highest termite mortality after $7 \mathrm{~d}$, followed by $\beta$-myrcene (7.3\%), $\alpha$-cadinol (5.3\%), $\beta$-pinene (4.0\%), $\alpha$-pinene $(2.7 \%)$, T-muurolol (2.0\%), and limonene (1.3\%). When the test was extended to $14 \mathrm{~d}$, termite mortality increased slightly (Table 2 ).

The antitermitic activities of eight isolated oil constituents at $5 \mathrm{mg} / \mathrm{g}$ dosages are presented in Figure 3. The order of antitermitic activity was T-muurolol, followed by $\beta$-caryophyllene, caryophyllene oxide, $\alpha$-cadinol, $\beta$-myrcene, $\beta$ pinene, $\alpha$-pinene, and then limonene. The respective termite mortalities (at $5 \mathrm{mg} / \mathrm{g}$ dosage after $14 \mathrm{~d}$ ) were $100.0 \%, 44.0 \%, 35.3 \%, 30.0 \%, 18.7 \%, 14.0 \%, 10.7 \%$, and $8.0 \%$. These results agree with those of Ohtani et al. (1997), who also reported the antitermitic activity of $\alpha$-cadinol and T-muurolol isolated from Chamaecyparis obtusa heartwood.

Antifungal Activity of Essential Oil. Figure 4 shows the antifungal index of $C$. formosana leaf essential oil. The constituents were effective in reducing the growth of L. betulina, P. coccineus, T. versicolor, and L. sulphureus at $1000 \mu \mathrm{g} / \mathrm{ml}$ compared with the untreated control. The antifungal indices of the leaf essential oil were $18.9,67.7,10.9$, and $27.6 \%$ against $L$. betulina, P. coccineus, $T$. versicolor, and L. sulphureus, respectively.

Antifungal Activity of Isolated Constituents. The antifungal indices of the eight compounds at a concentration of $100 \mu \mathrm{g} / \mathrm{ml}$ against the four fungi are 


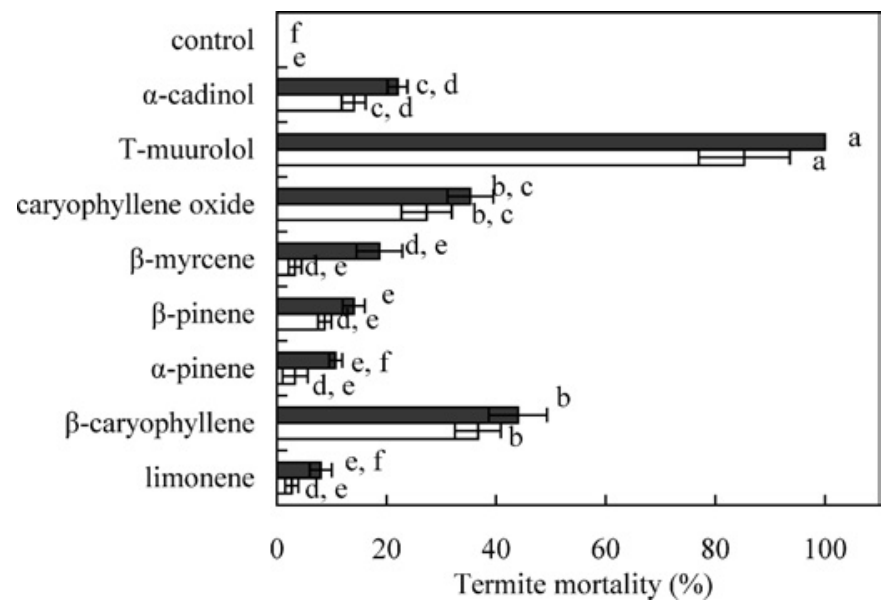

FIG. 3. Antitermitic activity of eight constituents from Calocedrus formosana leaf essential oil at $5 \mathrm{mg} / \mathrm{g}$ dosages against Coptotermes formosanus (white bar, after $7 \mathrm{~d}$; black bar, after $14 \mathrm{~d})$. Means $(N=3)$ using 50 termites per replicate. Numbers followed by different letters (a-f) are significantly different at the level of $P<0.05$ according to the Scheffe test.

presented in Table 3. The brown-rot fungus was more sensitive to the compounds than the white-rot fungi. In addition, two sesquiterpenes ( $\alpha$-cadinol and T-muurolol) were more effective against the four assay fungi than the monoterpenes. The order of antifungal indices of the eight compounds for L. sulphureus was $\alpha$-cadinol $>$ T-muurolol $>$ caryophyllene oxide $>\beta$-caryophyllene $>\beta$-myrcene

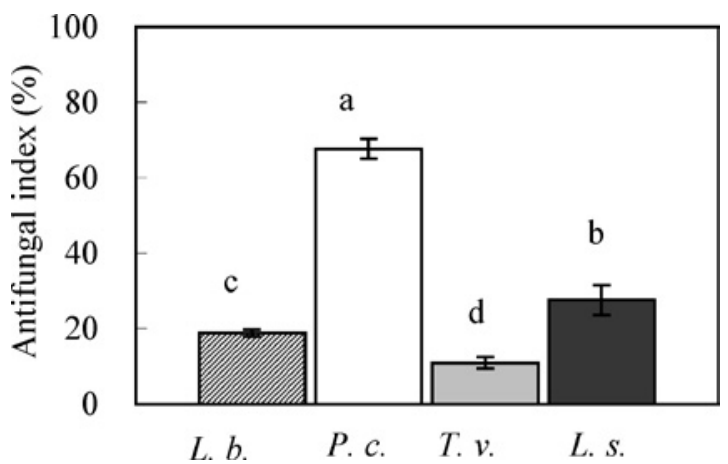

FIG. 4. Antifungal activity of leaf essential oil from Calocedrus formosana against fungi (at $1000 \mu \mathrm{g} / \mathrm{ml})$. Each experiment was performed $\times 3$ and the data averaged $(N=3)$. Numbers followed by different letters (a-d) are significantly different at the level of $P<0.05$ according to the Scheffe test. 
TABle 3. AnTIFUngal ACtivity of ESSENTIAL Oil CONSTITUENTS FROM Calocedrus formosana LEAVES AT $100 \mu \mathrm{g} / \mathrm{ml}^{a}$

\begin{tabular}{lrrrl}
\hline \multicolumn{1}{c}{ Constituents } & L. betulina & P. coccineus & T. versicolor & \multicolumn{1}{c}{ L. sulphureus } \\
\hline Limonene & $0.0 \pm 0.0 \mathrm{c}$ & $0.0 \pm 0.0 \mathrm{c}$ & $0.0 \pm 0.0 \mathrm{c}$ & $21.7 \pm 1.2 \mathrm{~d}, \mathrm{e}$ \\
$\alpha$-Pinene & $0.0 \pm 0.0 \mathrm{c}$ & $0.0 \pm 0.0 \mathrm{c}$ & $0.0 \pm 0.0 \mathrm{c}$ & $19.0 \pm 2.6 \mathrm{e}, \mathrm{f}$ \\
$\beta$-Pinene & $0.0 \pm 0.0 \mathrm{c}$ & $0.0 \pm 0.0 \mathrm{c}$ & $0.0 \pm 0.0 \mathrm{c}$ & $17.3 \pm 0.8 \mathrm{f}$ \\
$\beta$-Myrcene & $0.0 \pm 0.0 \mathrm{c}$ & $0.0 \pm 0.0 \mathrm{c}$ & $0.0 \pm 0.0 \mathrm{c}$ & $20.4 \pm 3.2 \mathrm{e}, \mathrm{f}$ \\
$\beta$-Caryophyllene & $0.0 \pm 0.0 \mathrm{c}$ & $0.0 \pm 0.0 \mathrm{c}$ & $0.0 \pm 0.0 \mathrm{c}$ & $24.8 \pm 2.4 \mathrm{~d}$ \\
Caryophyllene oxide & $0.0 \pm 0.0 \mathrm{c}$ & $0.0 \pm 0.0 \mathrm{c}$ & $0.0 \pm 0.0 \mathrm{c}$ & $32.3 \pm 2.0 \mathrm{c}$ \\
T-Muurolol & $48.0 \pm 0.0 \mathrm{~b}$ & $38.1 \pm 1.0 \mathrm{~b}$ & $48.0 \pm 5.8 \mathrm{~b}$ & $82.0 \pm 0.0 \mathrm{~b}$ \\
$\alpha$-Cadinol & $100.0 \pm 0.0 \mathrm{a}$ & $65.1 \pm 1.4 \mathrm{a}$ & $100.0 \pm 0.0 \mathrm{a}$ & $100.0 \pm 0.0 \mathrm{a}$ \\
\hline
\end{tabular}

${ }^{a}$ Each experiment was performed three times, and the data averaged $(N=3)$. Numbers followed by different letters $(\mathrm{a}-\mathrm{f})$ are significantly different at the level of $P<0.05$ according to the Scheffe test.

$>\alpha$-pinene $>$ limonene $>\beta$-pinene. Among them, $\alpha$-cadinol and T-muurolol exhibited a higher antifungal activity.

The antifungal effectiveness of $\alpha$-cadinol and T-muurolol were examined in greater detail. Figure 5 shows the antifungal indices of $\alpha$-cadinol at serial concentrations. It appears that $\alpha$-cadinol inhibited completely the growth of $L$. betulina, P. coccineus, T. versicolor, and L. sulphureus at a level as low as $200 \mu \mathrm{g} / \mathrm{ml}$.

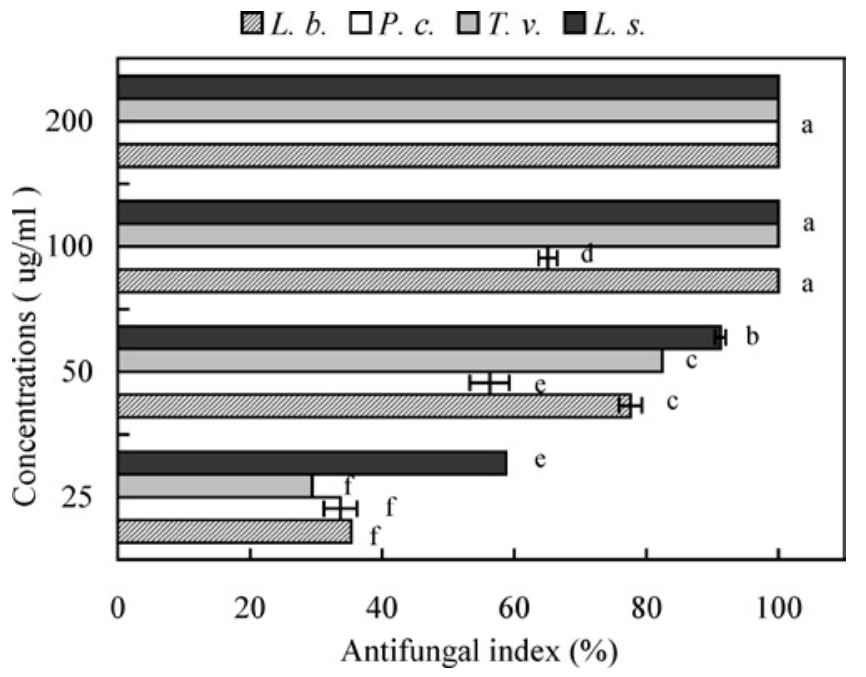

FIG. 5. Antifungal activity of $\alpha$-cadinol at serial concentrations against fungi. Each experiment was performed $\times 3$ and the data averaged $(N=3)$. Numbers followed by different letters (a-f) are significantly different at the level of $P<0.05$ according to the Scheffe test. 


\begin{tabular}{|c|c|c|c|c|}
\hline Constituents & L. betulina & P. coccineus & T. versicolor & L. sulphureus \\
\hline$\alpha$-Cadinol & 28.6 & 108.4 & 30.4 & 9.9 \\
\hline T-Muurolol & 93.3 & 74.1 & 81.0 & 57.3 \\
\hline
\end{tabular}

Similar results were obtained with T-muurolol. Table 4 shows the $\mathrm{LC}_{50}$ values of these compounds. It is noteworthy that $\alpha$-cadinol exhibited the highest antifungal index for L. betulina, P. coccineus, T. versicolor, and L. sulphureus, followed by T-muurolol. The $\mathrm{LC}_{50}$ values of $\alpha$-cadinol against $L$. betulina, $P$. coccineus, $T$. versicolor, and $L$. sulphureus are 28.6, 108.4, 30.4 and $9.9 \mu \mathrm{g} / \mathrm{ml}$, respectively. Further, the $\mathrm{LC}_{50}$ values of T-muurolol against four fungi are all below $93.3 \mu \mathrm{g} / \mathrm{ml}$. These results demonstrate that $\alpha$-cadinol and T-muurolol showed the significant growth inhibitory effect on all test fungi. In our previous studies on the antifungal performance of $T$. cryptomerioides extractives, $\alpha$-cadinol exhibited the highest antifungal activity for both $T$. versicolor and $L$. sulphureus, followed by T-cadinol, T-muurolol, ferruginol, and taiwanin C. There have been several reports that $\alpha$ cadinol exhibits significant effectiveness in durable tree species against fungi or termites (Kondo and Imamura, 1986; Kinjo et al., 1988; Chang et al., 1998, 1999, 2000). The antifungal activity of leaf essential oil isolated from C. formosana was attributed to $\alpha$-cadinol and T-muurolol, or their synergistic effect.

In addition, Table 4 also showed that the antifungal activity of two compounds were higher against brown-rot fungi than against white-rot fungi. Brown- and white-rot fungi decay wood by distinctly different mechanisms. The degradation of wood by white-rot fungi is carried out by enzymes such as cellulase or laccase. The initial stages of brown-rot fungal decay involve oxidative degradation (Highley and Dashek, 1998). DPPH is a stable radical that has been commonly used to evaluate the antioxidant activity of plant and microbial extracts (Gyamfi et al., 1999; Chang et al., 2001c; Wang et al., 2001). Results from our preliminary study showed that both $\alpha$-cadinol and T-muurolol have inhibitory activity against the DPPH radical (data not shown here), suggesting that they possess some kind of antioxidant activity to prevent the deterioration induced by brown-rot fungi. The significance of antioxidant activities for the cadinane compounds is under investigation and will be addressed in the near future.

In this study, we investigated antitermitic and antifungal activities of leaf essential oil from C. formosana against termite and wood decay fungi. Antitermitic tests demonstrated that $C$. formosana leaf essential oil exhibited antitermitic activity. The $\mathrm{LC}_{50}$ value of leaf essential oil against $C$. formosanus was $27.6 \mathrm{mg} / \mathrm{g}$ after $14 \mathrm{~d}$. Major constituents of $C$. formosana leaf essential oil were identified by 
GC-MS. According to antitermitic activity, T-muurolol showed $100 \%$ mortality at $5 \mathrm{mg} / \mathrm{g}$ after $14 \mathrm{~d}$. Its antitermitic effectiveness is much higher than that using C. formosana leaf essential oil. In addition, comparisons of the antifungal effectiveness of these compounds revealed that, among the eight compounds tested, $\alpha$-cadinol, T-muurolol, and caryophyllene oxide possessed stronger antifungal activity. $\alpha$-Cadinol exhibited the highest antifungal index for L. betulina, T. versicolor, and L. sulphureus, it inhibited completely the growth of fungi at levels as low as $100 \mu \mathrm{g} / \mathrm{ml}$. These results show that $\alpha$-cadinol and T-muurolol are potential compounds for the development of fungicides or termiticides in the near future.

Acknowledgments-This study was supported by a grant (NSC-91-2313-B-002-380) from the National Science Council of the Republic of China. The authors thank the National Science Council for the financial support and Mr. Tso-Yuan Hsieh (The Experimental Forest of National Taiwan University) for providing C. formosana materials and Mr. Chien-Yung Hung and Mr. Wen-Ching Cheng (Jong Shing Pest Control Co., Ltd.) for providing the termites and Dr. T.-T. Chang (Taiwan Forest Research Institute) and research center of the Food Industry Research and Development Institute for providing the fungi.

\section{REFERENCES}

AsAdA, T., IShimoto, T., SAKAI, A., and SumiYA, K. 1989. Insecticidal and antifungal activity in hinoki-asunaro leaf oil. Mokuzai Gakkaishi 35:851-855.

CHANG, H. T., YeH, T. F., and CHANG S. T. 2002. Comparisons of chemical characteristic variations for photodegraded softwood and hardwood with/without polyurethane clear coatings. Polym. Degrad. Stab. 77:129-135.

ChAng, S. T., ChEN, P. F., WANG, S. Y., and WU, H. H. 2001a. Antimite activity of essential oils and their constituents from Taiwania cryptomerioides. J. Med. Entomol. 38:455-457.

CHANG, S. T. and CHENG, S. S. 2002. Antitermite activity of leaf essential oils and their constituents from Cinnamomum osmophloeum. J. Agric. Food Chem. 50:1389-1392.

Chang, S. T., Cheng, S. S., and Wang, S. Y. 2001b. Antitermitic activity of essential oils and components from Taiwania (Taiwania cryptomerioides). J. Chem. Ecol. 27:717-724.

Chang, S. T., WANG, S. Y., Wu, C. L., Chen, P. F., and KuO, Y. H. 2000. Comparison of the antifungal activity of cadinane skeletal sesquiterpenoids from Taiwania (Taiwania cryptomerioides Hayata) heartwood. Holzforschung 54:241-245.

Chang, S. T., WANG, S. Y., WU, C. L., Su, Y. C., and KuO, Y. H. 1999. Antifungal compounds in the ethyl acetate soluble fraction of the extractives of Taiwania (Taiwania cryptomerioides Hayata) heartwood. Holzforschung 53:487-490.

Chang, S. T., Wu, C. L., Wang, S. Y., Su, Y. C., and KuO, Y. H. 1998. Studies on the antifungal compounds in the heartwood extractives of Taiwania (Taiwania cryptomerioides Hayata) (I): Isolation and identification of antifungal compounds in hexane soluble fraction. For. Prod. Ind. 17:287-304.

Chang, S. T., Wu, J. H., Wang, S. Y., Kang, P. L., YANG, N. S., and ShyuR, L. F. 2001c. Antioxidant activity of extracts from Acacia confusa bark and heartwood. J. Agric. Food Chem. 49:3420-3424.

Cheng, S. S. and Chang, S. T. 2002. Antitermitic activity of essential oils from Cryptomeria japonica. Q.J.Chin. For. 35:193-199.

Cheng, Y. S., Lo, T. B., Chang, L. H., and Lin, Y. T. 1961. Study of the extractives constituents from the wood of Libocedrus formosana Florin. IV. Partial hydrogenation of thujic acid. J. Chin. Chem. Soc. 8:103-108. 
FANG, J. M., HsU, K. C., and CHENG, Y. S. 1989a. Terpenoids from leaves of Calocedrus formosana. Phytochemistry 28:1173-1175.

FANG, J. M., Hsu, K. C., and CHENG, Y. S. 1989b. Lignans from leaves of Calocedrus formosana. Phytochemistry 28:3553-3555.

FANG, J. M., JAN, S. T., and CHENG, T. S. 1985. (+)-Calocedrin, a lignan dehydroanhydride from Calocedrus formosana. Phytochemistry 24:1863-1864.

FANG, J. M., JAN, S. T., and CHENG, T. S. 1987. Terpenoids from Calocedrus formosana. Phytochemistry 26:853-854.

GYAMFI, M. A., YONAMINE, M., and ANIYA, Y. 1999. Free-radical scavenging action of medicinal herbs from Ghana Thonningia sanguinea on experimentally-induced liver injuries. Gen. Pharmacol. 32:661-667.

HighleY, T. L. and DASHEK, W. V. 1998. Biotechnology in the study of brown- and white-rot decay, pp. 15-36, in A. Bruce and J. W. Palfreyman (eds.). Forest Products Biotechnology. Taylor \& Francis, Bristol, PA.

Kang, H. Y., Matsushima, N., SAmeshima, K., and TaKamura, N. 1990. Termite resistance tests of hardwoods of Kochi growth. I. The strong termiticidal activity of kagonoki (Litsea coreana Léveillé). Mokuzai Gakkaishi 36:78-84.

KINJO, K., DoufUKU, Y., and YAGA, S. 1988. Termiticidal substances from the wood of Chamaecyparis obtusa. Mokuzai Gakkaishi 34:451-455.

KINJO, K. and YATA, S. 1986. Study on the cultivation culture media of basidiomycetes. IV. Antifungal activity of hinoki. Mokuzai Gakkaishi 32:632-636.

Kondo, R. and ImAmurA, H. 1986. Antifungal compounds in heartwood extractives of hinoki (Chamaecyparis obtusa End1.). Mokuzai Gakkaishi 32:213-217.

LIN, Y. T., LO, T. B., and LIN, T. H. 1956. Study of the extractives constituents from the wood of Libocedrus formosana Florin. II. Interconversion between isoshonanic acid and thujic acid. $J$. Chin. Chem. Soc. 3:36-40.

LO, T. B. and LIN, Y. T. 1956. Study of the extractives constituents from the wood of Libocedrus formosana Florin. I. J. Chin. Chem. Soc. 3:30-35.

Mikage, M., Ohtsubo, H., and Namba, T. 1988. Pharamacognostical studies on the Chinese crude drug "Ce bai ye" (III) on the botanical origin of "Ce bai ye" from Taiwan. Shoyakugaku Zasshi 42:125-129.

MoritA, S. I., HidAKA, T., and YATAGAI, M. 1997. Antifungal components of the extactives of yakusugi (Crypotomeria japonica D. Don). Wood Preservation 23:11-19.

Nabeta, K., Katayama, K., Matsubara, M., Hatakeyama, C., Shimada, T., Tazaki, H., OKuyama, H., and MIYAKE, M. 1992. Oxygenated sesquiterpenes from needles of korean pine (Pinus Koraiensis Sieb. et Zucc.). Mokuzai Gakkaishi 38:963-971.

Ohtani, Y., HaZAma, M., and SAmeshima, K. 1997. Crucial chemical factors of the termiticidal activity of Hinoki wood (Chamaecyparis obtusa) III. Contribution of $\alpha$-terpinyl acetate to the termiticidal activity of hinoki wood. Mokuzai Gakkaishi 43:1022-1029.

ONO, M., ASAI, T., and WATANABE, H. 1998. Hinokitiol production in a suspension culture of Calocedrus formosana Florin. Biosci. Biotechnol. Biochem. 62:1653-1659.

WANG, S. Y., WU, J. H., SHYUR, L.-F., KUO, Y.-H., and CHANG, S. T. 2001. Antioxidant activity of abietane-type diterpenes from heartwood of Taiwania cryptomerioides Hayata. Holzforschung 56:487-492.

Yoneyama, S., Togashi, I., OIKaWA, H., and Aoyama, M. 1990. An antifungal substance in the volatile wood-oil of todomatsu, Abies sachalinensis Mast. Mokuzai Gakkaishi 36:777-780. 